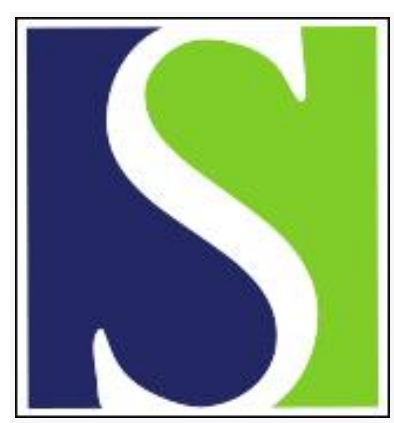

Scand J Work Environ Health 1983;9(6):489-495

https://doi.org/10.5271/sjweh.2384

Issue date: Dec 1983

Sampling and analysis of hexavalent chromium during exposure to chromic acid mist and welding fumes.

by Blomquist $\mathrm{G}$, Nilsson CA, Nygren $\mathrm{O}$

This article in PubMed: www.ncbi.nlm.nih.gov/pubmed/6673106

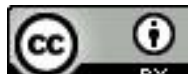




\title{
Sampling and analysis of hexavalent chromium during exposure to chromic acid mist and welding fumes
}

\author{
by Göran Blomquist, PhD, Carl-Axel Nilsson, PhD, Olle Nygren, BSc ${ }^{1}$
}

\begin{abstract}
BLOMQUIST G, NILSSON C-A, NYGREN O. Sampling and analysis of hexavalent chromium during exposure to chromic acid mist and welding fumes. Scand $j$ work environ \& health 9 (1983) 489-495. In view of the serious health effects of hexavalent chromium, the problems involved in its sampling and analysis in workroom air have been the subject of much concern. In this paper, the stability problems arising from the reduction of hexavalent to trivalent chromium during sampling, sample storage, and analysis are discussed. Replacement of sulfuric acid by a sodium acetate buffer $(\mathrm{pH} 4)$ as a leaching solution prior to analysis with the diphenylcarbazide (DPC) method is suggested and is demonstrated to be necessary in order to avoid reduction. Field samples were taken from two different industrial processes-manual metal arc welding on stainless steel without shield gas and chromium plating. A comparison was made of the DPC method, acidic dissolution with atomic absorption spectrophotometric (AAS) analysis, and the carbonate method. For chromic acid mist, the DPC method and AAS analysis were shown to give the same results. In the analysis of welding fumes, the modified DPC method gave the same results as the laborious and less sensitive carbonate method.
\end{abstract}

Key terms: atomic absorption spectrophotometry, carbonate, diphenylcarbazide, plating, work environment.

Chromium is widely used in various industrial applications - such as plating, tanning, metallurgy, welding and wood preservation - and gives rise to occupational problems in many work environments. Hexavalent chromium is suggested to be the most toxic form of chromium in view of its ability to penetrate cell membranes and its strong oxidizing effect on biological materials. Known toxic effects are ulcers, perforation of the nasal septa, sinusitis, laryngitis, and asthma. Bronchial carcinogenesis and gastrointestinal diseases have also been reported $(6,7)$.

Numerous studies on various aspects of chromium are reported in the literature. Recently analytical methods for

1 National Board of Occupational Safety and Health, Department of Occupational Health in Umeå, S-900 06 Umeå, Sweden.

Reprint requests to: Dr C-A Nilsson, National Board of Occupational Safety and Health, Department of Occupational Health in Umeå, Box 6104, S-900 06 Umeå, Sweden. the analysis of chromium in water (11), biological material (14), and in the environment and workplace (12) have been reviewed. Specific analytical methods for hexavalent chromium $\left(\mathrm{Cr}^{6+}\right)$ are, due to its serious health effects, of great interest, especially for samples from work environments.

In the control of occupational exposure, biological monitoring is also a useful tool (10), especially when skin contact is possible (eg, tanning, working with cement).

Analytical methods used for the preparation of air samples from the occupational environment are different extraction procedures with complexing agents like ammonium pyrrolidine dithiocarbamate (APDC) (2) or selective leaching $(8,13)$. The analysis is then performed with spectrophotometric methods or atomic absorption spectrophotometry (AAS).

The present communication provides a practical and simple approach to some 
of the most frequent types of samples taken from workroom air, ie, chromic acid mist and welding fumes. Other methods discussed in the literature for these types of samples are sulfuric acid extraction followed by diphenylcarbazide (DPC) complexation and spectrophotometric determination (1) and carbonate leaching prior to DPC complexation (8) or AAS (13). These methods are compared and discussed in relation to the modified DPC method proposed in this paper.

\section{Materials and methods}

\section{Chemicals}

All the chemicals were of analytical grade or higher quality. Water was purified in a Millipore $R / Q$ water purifier. Sodium acetate buffer $(0.1 \mathrm{M} \mathrm{NaAc}$ buffer, $\mathrm{pH} 4)$ was prepared by the addition of $20 \mathrm{ml}$ of $0.1 \mathrm{M}$ acetic acid to $80 \mathrm{ml} 0.1 \mathrm{M}$ sodium acetate. The DPC reagent was prepared by the dissolution of $0.5 \mathrm{~g}$ of DPC (Merck) in $100 \mathrm{ml}$ of acetone and the addition of water to $200 \mathrm{ml}$. The DPC reagent can be stored in a dark bottle at $4^{\circ} \mathrm{C}$ for at least one month. The aqua regia was made by the mixing of two parts of concentrated nitric acid (suprapur, Merck), one part of concentrated hydrochloric acid (suprapur, Merck), and one part of water. Stock solutions of chromium were $1,000 \mathrm{mg} / \mathrm{ml}$ of potassium dichromate and
$1,000 \mathrm{mg} / \mathrm{ml}$ of chromium trioxide $\left(\mathrm{Cr}^{6+}\right)$ and a commercial atomic absorption standard, 1,000 mg of trivalent chromium $\left(\mathrm{Cr}^{3+}\right)$ per milliliter (British Drug House Chemicals Ltd) for the analysis of total chromium.

\section{Sampling material and glassware}

All glassware was washed with tap water and detergent, soaked in concentrated nitric acid, and then thoroughly rinsed with deionized water. The filters used for the stability tests were Millipore AAWP (cellulose esters, $0.8 \mu \mathrm{m}$ ), Millipore BSWP (polyvinyl chloride, $2.0 \mu \mathrm{m}$ ), Gelman DM 800 (polyvinyl chloride, $0.8 \mu \mathrm{m}$ ) and Whatman GF/A (glass fiber). Millipore BSWP was used for the sampling of workroom air. Air was passed through the filter with the use of a Casella membrane pump with an approximate flow rate of $1 \mathrm{l} / \mathrm{min}$. The exact flow rate was measured with a precision rotameter every $15 \mathrm{~min}$. If the variation in rate exceeded $10 \%$, the sample was discarded.

\section{Instrumentation}

For the spectrophotometric determinations, we used a Pye Unicam SP1700 ultraviolet spectrophotometer operated at $544 \mathrm{~nm}$ with a $4-\mathrm{cm}$ cuvette. The AAS determinations were performed with a Pye Unicam SP1900 atomic absorption

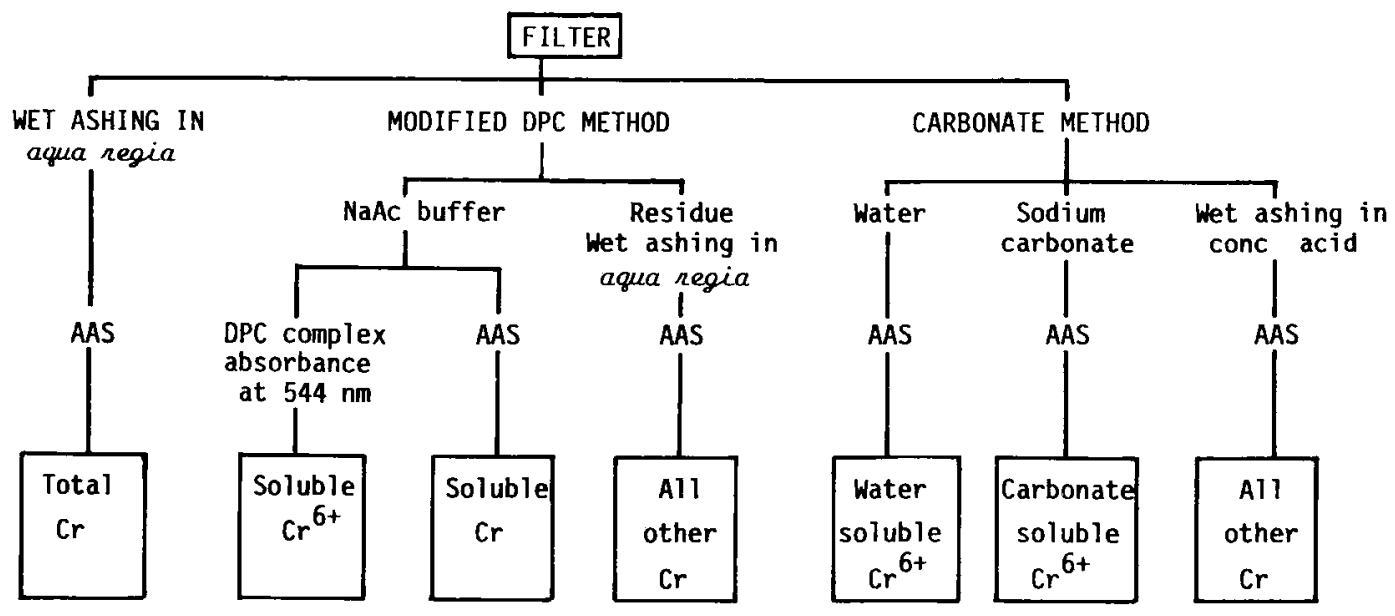

Fig 1. Analytical scheme. (DPC = diphenylcarbazide. $\mathrm{NaAc}=$ sodium acetate, $\mathrm{AAS}=$ atomic absorption spectrophotometry, $\mathrm{Cr}=$ chromium, $\mathrm{Cr} 6+=$ hexavalent chromium, conc $=$ concentrated) 
spectrophotometer. Chromium was measured at $357.9 \mathrm{~nm}$ in a nitrogen oxide/ acetylene flame.

\section{Sampling}

Airborne chromic acid was sampled in a chromium-plating plant. Samples were collected above the plating bath and in the breathing zone of the workers. Manual metal arc welding was performed in a workshop under normal ventilation with electrode OK 63.30 (18.5\% chromium, $12.5 \%$ nickel) $4 \times 350 \mathrm{~mm}$ on stainless steel SIS 2543 (17 \% chromium, $11.5 \%$ nickel) on a welding bench in the center of the room.

\section{Analysis}

The various methods used for analyzing chromium are summarized in fig 1 . A detailed description is given below.

Total amount of chromium. The filters were treated in $10 \mathrm{ml}$ of aqua regia on a water bath $\left(80^{\circ} \mathrm{C}\right)$ for $2 \mathrm{~h}$. The samples were filtered and diluted to $15 \mathrm{ml}$ with water. Samples and suitable reference standards $\left(\mathrm{Cr}^{3+}\right)$ in the same matrix were then analyzed for chromium with AAS.

Hexavalent chromium, modified diphenylcarbazide method. The filters were shaken in $7 \mathrm{ml}$ of $\mathrm{NaAc}$ buffer for $3 \mathrm{~min}$ and then twice in $3 \mathrm{ml}$ for $1 \mathrm{~min}$. For samples stored for more than one week, the leaching time was extended to $15 \mathrm{~min}$. The volume of the combined extracts was adjusted to $15 \mathrm{ml}$ with the $\mathrm{NaAc}$ buffer. (Any undissolved residues were saved for the determination of the total amount of chromium.) Depending on the concentration, $1-10 \mathrm{ml}$ of the samples was further diluted with $\mathrm{NaAc}$ buffer to $10 \mathrm{ml}$. Then $0.5 \mathrm{ml}$ of the $\mathrm{DPC}$ reagent was added, and the volume increased to $15 \mathrm{ml}$ with $0.3 \mathrm{M}$ sulfuric acid. Samples and suitable standards $\left(\mathrm{Cr}^{6+}\right)$, prepared in the same matrix, were allowed to stand for $15 \mathrm{~min}$ before the colorimetric determination so that the violet-colored complex could develop. In the remaining NaAc extracts the total amount of chromium was determined by AAS using the $\mathrm{Cr}^{6+}$ standard.
Hexavalent chromium, carbonate method. The carbonate method, as described by Thomsen \& Stern (13), is based on a fractionated extraction of $\mathrm{Cr}^{6+}$. First, water-soluble chromates (eg, $\mathrm{Na}^{+}$or $\mathrm{K}^{+}$salts) are extracted with water. Second, chromates that are not readily soluble (eg, $\mathrm{Pb}^{2+}$ and $\mathrm{Ba}^{2+}$ salts) are dissolved in boiling sodium carbonate solution. Finally, chromium compounds that are the most difficult to dissolve are treated in boiling, concentrated mineral acid or, if necessary, with some kind of incineration (eg, hydrofluoric acid or sodium peroxide). The three fractions are then analyzed for chromium with AAS and compared with suitable standards ( $\mathrm{Cr}^{6+}$ or $\mathrm{Cr}^{3+}$ ) in the same matrix. The total amount of chromium is then calculated by the summing of the amount of chromium in each fraction.

\section{Results and discussion}

Stability of hexavalent chromium during sampling, sample storage and analysis

For a specific determination of $\mathrm{Cr}^{6+}$ any interference which may cause reduction to the trivalent form must be avoided. In the preparation of the sample for analysis by the DPC method, Abell \& Carlberg recommend leaching in $0.5 \mathrm{M}$ sulfuric acid (1). This procedure results however in a significant reduction $(3,9)$ of $\mathrm{Cr}^{6+}$ within $10 \mathrm{~min}$. In order to avoid this reduction, the stability of $\mathrm{Cr}^{6+}$ in an $\mathrm{NaAc}$ buffer was studied and compared with that in sulfuric acid. From the results it is obvious that the NaAc buffer is more suitable for leaching the filters than an acid solution is (fig 2 ).

A method recently proposed by the US National Institute for Occupational Safety and Health (8) is based on alkaline carbonate leaching of the samples prior to DPC analysis. However, Carelli et al (4) reported that, if sodium carbonate is used for leaching the filters, the absorbance of the sample decreases as a function of time. The average depressive effect was reported to be $26 \%$. Therefore the stability of the DPC complex in the NaAc buffer was investigated with the use of two different $\mathrm{Cr}^{6+}$ compounds potassium dichromate and chromic acid. 


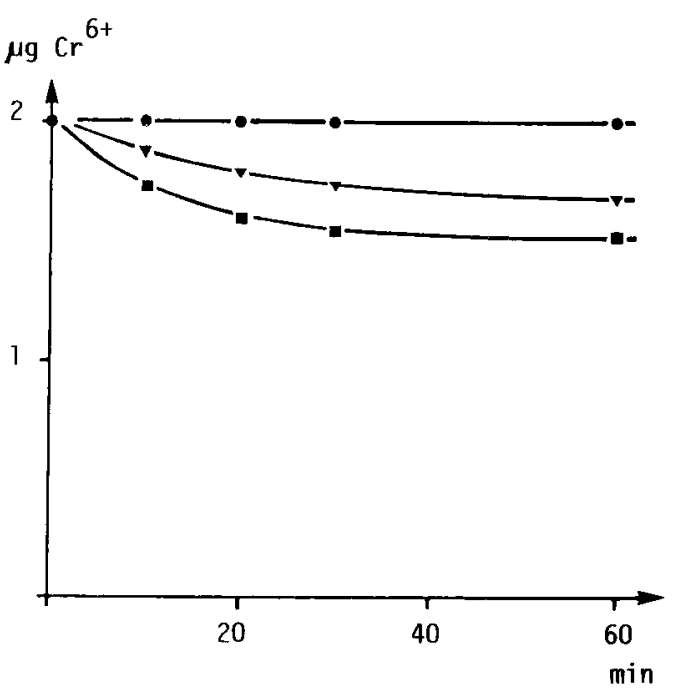

Fig 2. Stability of hexavalent chromium $\left(\mathrm{Cr}^{6+}\right)$ in various solutions with increasing storage time prior to analysis. $(\boldsymbol{\theta}=$ sodium acetate buffer, $\mathrm{pH} 4 ; \boldsymbol{\nabla}=0.1 \mathrm{M}$ sulfuric acid; $\boldsymbol{\square}=0.25 \mathrm{M}$ sulfuric acid)

Table 1. Stability of the complex between hexavalent chromium ( $\left.\mathrm{Cr}^{6 r}\right)$, added as potassium dichromate $\left(\mathrm{K}_{2} \mathrm{Cr}_{2} \mathrm{O}_{7}\right)$ or chromium trioxide $\left(\mathrm{CrO}_{3}\right)$, and diphenylcarbazide in sodium acetate buffer at $\mathrm{pH} 4$. Mean value of four determinations. (2 $\mu \mathrm{g}$ chromium sample)

\begin{tabular}{ccc}
\hline & \multicolumn{2}{c}{ Recovery of $\mathrm{Cr}^{6+}(\%)$} \\
\cline { 2 - 3 } Time & $\mathrm{K}_{2} \mathrm{Cr}_{2} \mathrm{O}_{7}$ & $\mathrm{CrO}_{3}$ \\
\hline $5 \mathrm{~min}$ & 100 & \\
$15 \mathrm{~min}$ & 100 & 100 \\
$30 \mathrm{~min}$ & 100 & 100 \\
$1 \mathrm{~h}$ & 98 & 100 \\
$1.5 \mathrm{~h}$ & 97 & 99 \\
$2 \mathrm{~h}$ & 95 & 97 \\
$24 \mathrm{~h}$ & -60 & 95 \\
\hline
\end{tabular}

Table 2. Recovery of hexavalent chromium $\left(\mathrm{Cr}^{6+}\right)$ from various types of filter. $(3 \mu \mathrm{g}$ of hexavalent chromium was added as potassium dichromate to each filter)

\begin{tabular}{lccccc}
\hline & \multicolumn{5}{c}{ Recovery } \\
\cline { 2 - 6 } Filter & \multicolumn{2}{c}{$25 \mathrm{~h}$} & & \multicolumn{2}{c}{1 week } \\
\cline { 2 - 6 } & $\%$ & $\mathrm{~N}$ & & $\%$ & $\mathrm{~N}$ \\
\hline $\begin{array}{l}\text { Millipore BSWP } \\
\text { (polyvinyl chloride) }\end{array}$ & 93 & 5 & & 93 & 4 \\
$\begin{array}{l}\text { Gelman DM 800 } \\
\text { (polyvinyl chloride) }\end{array}$ & 95 & 5 & & 88 & 4 \\
$\begin{array}{l}\text { Millipore AAWP } \\
\text { (cellulose esters) }\end{array}$ & $<50$ & 5 & & - & - \\
$\begin{array}{l}\text { Whatman GF/A } \\
\text { (glass fiber) }\end{array}$ & 95 & 5 & & 94 & 4 \\
\hline
\end{tabular}

The results are shown in table 1 . The complex was sufficiently stable for $90 \mathrm{~min}$, which should be adequate to accomplish the analysis.

Another important factor to consider for the sampling of $\mathrm{Cr}^{6}+$ is possible reduction on the filter. This possibility was pointed out by Dutkiewicz et al (5), who showed that a cellulose acetate filter reduced the $\mathrm{Cr}^{6+}$ to $\mathrm{Cr}^{3+}$. Abell \& Carlberg (1) reported that the use of polyvinyl chloride filters (Gelman VM-1) eliminated the problem. In this study we determined the recovery of $\mathrm{Cr}^{6+}$ from four different types of filter (table 2). As expected, the cellulose ester filters gave a significant reduction of $\mathrm{Cr}^{6+}$. Reduction of $\mathrm{Cr}^{6+}$ in samples of welding fumes on cellulose ester filters was not studied. However, to avoid any possibility of reduction due to the filter material, these filters were not used for sampling in workroom air.

No reduction was observed on the polyvinyl chloride or glass fiber filters. If the filters were stored for several days, however, the $\mathrm{Cr}^{6+}$ was more difficult to recover from the filters. The leaching time had to be extended to at least $15 \mathrm{~min}$. This effect was especially pronounced for the Gelman DM 800 filters. The glass fiber filter, although no reduction was observed on it, was considered less suitable since disintegration made filtration or centrifugation necessary.

Another factor which might contribute to the reduction of $\mathrm{Cr}^{6+}$ is the presence of reducing components in the sample matrix. If organic dust is present in the samples, its influence on the stability of $\mathrm{Cr}^{6+}$ in the sample should be investigated for each type of sample matrix. Several other metals frequently occur along with chromium in work environments. Detailed investigations of the reductive effects of different metal ions on $\mathrm{Cr}^{6+}$ have been described in the literature $(4,9,13)$. Bivalent iron $\left(\mathrm{Fe}^{2+}\right)$ has been reported to be one of the most severely interfering ions and also a constituent of welding fumes (13). However, Naranjit et al (9) reported that no $\mathrm{Fe}^{2+}$ is extracted at levels higher than $\mathrm{pH} 3$. The use of NaAc buffer for leaching the samples thus solves the problem.

In order to demonstrate the stability of $\mathrm{Cr}^{6+}$ during the sampling and analysis of welding fumes and to determine the 
$\mathrm{Cr}^{6+} /$ total chromium ratio, we collected a number of samples in a small workshop. The welding was performed as manual metal arc welding on stainless steel without shield gas. $\mathrm{Cr}^{6+}$ was determined by the modified DPC method with NaAc buffer leaching. These results were compared to the level of total chromium obtained by the analysis of the NaAc buffer solution by AAS and also by the analysis of parallel samples with dissolution in aqua regia and AAS analysis. The remaining filters from the $\mathrm{NaAc}$ buffer leaching were also dissolved in aqua regia and analyzed by AAS, and the chromium residue was always less than $1 \%$. The results are shown in table 3 . Only a slight reduction could be observed after two weeks' storage. Thomsen \& Stern (13) claimed that the reduction they observed in similar samples was due to a matrix reductive effect. They used cellulose filters for sampling, however, which might cause reduction.

\section{Comparison of the diphenylcarbazide method and atomic absorption spectro- photometry in the analysis of chromium in samples from a chromium-plating plant}

In the plating process, hydrogen gas is evolved during electrolysis, and, when it leaves the plating bath, a mist of chromic acid is generated. In samples of this type, all chromium should be hexavalent and the analytical method, DPC or AAS, is just a matter of choice. However, flame AAS analysis is less sensitive and requires larger air samples, about $500 \mathrm{l}$, to obtain a practical detection limit of one-fifth of the Swedish hygienic standard. This amount should be compared to less than 151 with the proposed DPC method.

In order to verify that all chromium is hexavalent and that no reduction occurs in that type of matrix, we collected $\mathbf{4 0}$ samples in a chromium-plating plant. All filters (polyvinyl chloride, Millipore BSWP) were analyzed by the DPC method. The remaining $\mathrm{NaAc}$ extracts and aciddigested filter residues were then analyzed for total chromium. The results are presented in fig 3 , which shows that only $\mathrm{Cr}^{6+}$ was present. No reduction occurred, and both methods gave the same result.
Comparison of the modified diphenylcarbazide and carbonate methods

Samples of welding fumes from manual metal arc welding on stainless steel without shield gas were collected on polyvinyl chloride filters. Each filter was cut in half. One-half was analyzed by the modified DPC method, and the other by the carbonate method. The results are shown in table 4 . There was no significant difference in the levels of $\mathrm{Cr}^{6+}$. In the carbonate method, however, DPC analysis of the carbonate fraction is unsuitable since, according to Carelli et al (4), there

Table 3. The effect of storage time on hexavalent chromium in samples of welding fumes collected on polyvinyl chloride filters (Millipore BSWP). The loading on the filters was in the range of $20-$ $40 \mu \mathrm{g}$ of chromium.

\begin{tabular}{lccc}
\hline $\begin{array}{l}\text { Storage } \\
\text { time }\end{array}$ & $\begin{array}{c}\text { Hexavalent } \\
\text { chromium: } \\
\text { total chromium } \\
\text { ratio }\end{array}$ & $\begin{array}{c}\text { Relative } \\
\text { standard } \\
\text { deviation } \\
(\%)\end{array}$ & $\mathrm{N}$ \\
\hline $15 \mathrm{~min}$ & 1.05 & 4 & 17 \\
$1 \mathrm{~h}$ & 1.01 & 4 & 17 \\
$24 \mathrm{~h}$ & 1.07 & 3 & 18 \\
2 weeks & 0.93 & 6 & 17 \\
\hline
\end{tabular}

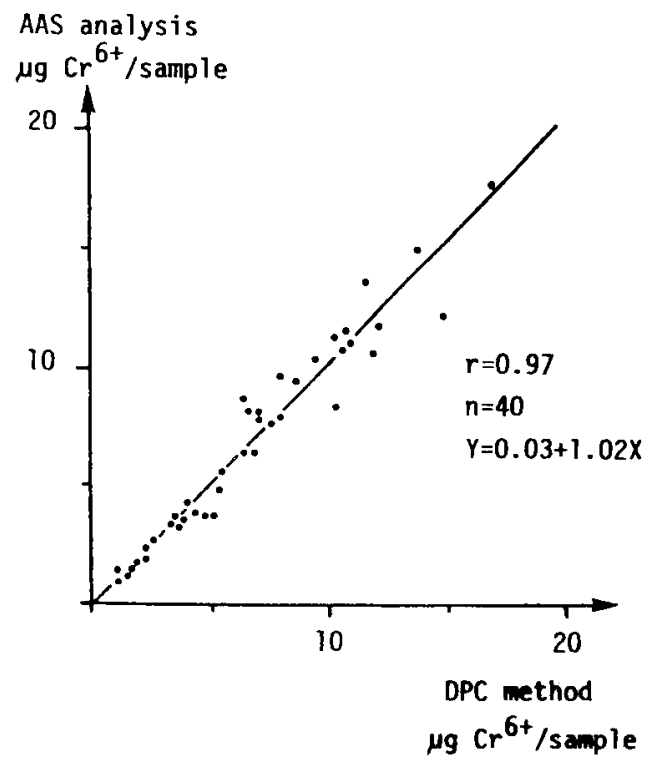

Fig 3. Comparison of the modified diphenylcarbazide (DPC) method with atomic absorption spectrophotometry (AAS) analysis in the case of samples taken on polyvinyl chloride filters in a chromium-plating plant. $\left(\mathrm{Cr}^{6+}=\right.$ hexavalent chromium) 
Table 4. Comparison of the modified diphenylcarbazide (DPC) and carbonate methods in the analysis of hexavalent chromium $\left(\mathrm{Cr}^{6+1}\right.$ in fumes from manual metal arc welding on stainless steel without shield gas. (Filters divided in two parts before the analysis.) Loading of hexavalent chrnmium on the filters was in the range of 10$40 \mu \mathrm{g}$.

\begin{tabular}{lcc}
\hline $\begin{array}{l}\mathrm{Cr}^{6+} \\
\left(\mathrm{mg} / \mathrm{m}^{3}\right)\end{array}$ & $\begin{array}{c}\text { Relative standard } \\
\text { deviation }(\%)\end{array}$ & $\mathrm{N}$ \\
\hline $\begin{array}{l}D C \text { method } \\
0.25\end{array}$ & 8 & 10 \\
$\begin{array}{l}\text { Carbonate method } \\
0.24\end{array}$ & 31 & 10 \\
\hline
\end{tabular}

is a risk of interference from the carbonate. The analysis was thus made by AAS, which makes the method less sensitive. In the carbonate method, about $20 \%$ of the $\mathrm{Cr}^{6+}$ was found in the carbonate fraction. All $\mathrm{Cr}^{6+}$ was soluble in the NaAc buffer. For these types of samples the modified DPC method thus gives the same result as the more laborious carbonate leaching method $(8,13)$.

\section{Conclusions}

For the sampling and analysis of $\mathrm{Cr}^{6+}$ in work environments, the modified DPC method described in this paper has proved to be suitable. A practical detection limit for the method is well below $2 \mu \mathrm{g} / \mathrm{m}^{3}$ for a 30-1 air sample. As also pointed out by Abell \& Carlberg (1), to avoid reduction of the $\mathrm{Cr}^{6+}$. sampling should be performed on polyvinyl chloride filters.

Fumes from welding on stainless steel are a source of occupational exposure to $\mathrm{Cr}^{6+}$. Manual metal are welding is frequently used, and the samples analyzed in this study showed that all chromium is present in the hexavalent state. The DPC method, based on sampling on polyvinyl chloride filters and NaAc buffer leaching, was demonstrated to give the same results as the more laborious carbonate method $(8,13)$. For metal inert gas welding on stainless steel, it has been reported that the total chromium content is a maximum of $14 \%$ and that the $\mathrm{Cr}^{6+}$ content is $0-0.3 \%$ (13). Hygienic standards in Sweden are $5 \mathrm{mg} / \mathrm{m}^{3}$ for dust, $0.5 \mathrm{mg} / \mathrm{m}^{3}$ for chromium, except $\mathrm{Cr}^{6+}$, and $0.02 \mathrm{mg} / \mathrm{m}^{3}$ for $\mathrm{Cr}^{6+}$. Therefore both the hygienic stan- dard for dust and chromium are, even in extreme cases, well exceeded before the level of $\mathrm{Cr}^{6+}$ reaches $0.02 \mathrm{mg} / \mathrm{m}^{3}$. Thus there is no need for a selective analysis of $\mathrm{Cr}^{6+}$ in samples from metal inert-gas welding. Simple dissolution in aqua regia and AAS analysis should be sufficient.

For the sampling and analysis of airborne $\mathrm{Cr}^{6+}$ in a chromium-plating plant, both the DPC method and the AAS analysis are suitable. The choice depends only on the sampling time and the analytical equipment available.

Because of the disturbance of carbonate already mentioned, the DPC method is less suitable for the analysis of samples containing carbonate, eg, cement dust.

\section{Acknowledgment}

The authors are indebted to Dr K Andersson for his critical reading of the manuscript and for his stimulating discussions.

\section{References}

1. Abell MT, Carlberg JR. A simple and reliable method for the determination of airborne hexavalent chromium. Am ind hyg assoc $\mathrm{j} 35$ (1974) 229-233.

2. Bergman $H$, Hardt $K$. Analysis of dissolved $\mathrm{Cr}^{3+}$ and $\mathrm{Cr}^{6+}$ in water by APDC-MIBK extraction and atomic absorption spectrometry. Fresenius Z Anal Chem 297 (1979) $381-382$

3. Blomquist G. Analysis and sampling of hexavalent chromium: I Investigation of diphenylcarbazide method [in Swedish]. National Board of Occupational Safety and Health, Stockholm 1977. (Investigation report 1977: 32).

4. Carelli G, LaBua R, Rimatori V, Porcelli D, Iannaccone A. Interferences in the spectrophotometric S-diphenylcarbazide determination of environmental hexavalent chromium in a chromium and zinc plating plant. Scand $\mathrm{j}$ work environ health 7 (1981) 56-61.

5. Dutkiewicz T, Konczalik J, Przechera M. Assessment of the colorimetric methods of determination of chromium in air and urine by means of radioisotope techniques. Acta pol pharm 26 (1969) 168-176.

6. Mancuso TF. Occupational cancer and other health hazards in a chromate plant: A medical appraisal. II Chemical and toxicological aspects. Ind med surg 20 (1951) 393-407.

7. National Institute for Occupational Safety and Health. Criteria for a recommended standard: Occupational exposure to chromium (VI). US Department of Health Education and Welfare, Washington, 
DC 1975 .

8. National Institute for Occupational Safety and Health. Manual of analytical methods. Volume 6 (Hexavalent chromium). US Department of Health and Human Services, Cincinnati, OH 1980. (Report 319).

9. Naranjit D, Thomassen Y, Van Loon JC. Development of a procedure for studies of the chromium (III) and chromium (VI) contents of welding fumes. Anal chim acta $110(1979): 2,307-312$.

10. Nise G, Vesterberg $O$. Direct determination of chromium in urine by electrothermal atomic absorption spectrometry. Scand j work environ health 5 (1979) $404-$ 410.

11. Rao VM, Sastri MN. Determination of chromium in natural waters - A review. $\mathrm{J}$ sci ind res 41 (1982) 607-615.

12. Slavin W. Determination of chromium in the environment and in the work place. At spectrose 2 (1981) 8-12.

13. Thomsen E, Stern RM. A simple analytical technique for the determination of hexavalent chromium in welding fumes and other complex matrices. Scand $\mathrm{j}$ work environ health 5 (1979) 386-403.

14. Torgrimsen T. Analysis of chromium. Top environ health 5 (1982) 65-69.

Received for publication: 6 April 1983 